\title{
Aplikasi Permainan Berbasis Android dalam Meningkatkan Kemampuan Kosakata Anak Tunarungu
}

\author{
Amanda Dina Qoyyimah, Eka Pramono Adi \\ Universitas Negeri Malang \\ Email: amandadina89@gmail.com
}

\begin{abstract}
Abstrak : Penelitian ini bertujuan untuk menghasilkan media pembelajaran melalui aplikasi permainan berbasis android untuk anak tunarungu kelas I yang layak digunakan untuk meningkatkan kemampuan kosakata. Metode penelitian yang digunakan adalah metode penelitian dan pengembangan (R\&D). Hasil uji coba kelompok kecil memperoleh rata-rata pre-test 63,33 dan post-test 83,33. Berdasarkan hasil uji coba, terdapat kenaikan nilai sebelum dan sesudah menggunakan media, maka media Aplikasi Permainan termasuk dalam kriteria sangat baik dan layak digunakan sebagai media pembelajaran kosakata siswa tunarungu kelas I di SLB Eka Mandiri Kota Batu secara individual maupun klasikal.
\end{abstract}

Kata Kunci : Pembelajaran berbasis media android, Kosakata, Tunarungu

\begin{abstract}
This study aims to produce instructional media through the application of the game based on android for children with hearing impairment on first class who deserve to be used to improve vocabulary skills. The research method used is research and development ( R \& D) method. The results of small group trials obtained an average of pre-test 63.33 and post-test 83.33. Based on the results of the trial, there is an increase in value before and after using the media, the media Application Game included in the criteria is very good and worthy to use as a media of vocabulary learning of students hearing of first grade SLB Eka Mandiri Batu City as individually and classical.
\end{abstract}

Keyword: Android Based Learning Media, Vocabulary, Hearing Impairment

Manusia dalam kehidupan sehari-hari sebagai makhluk sosial menggunakan komunikasi dengan suatu media, yaitu bahasa. Dalam berbahasa, penggunaan katakata yang baik dan benar dapat membantu dalam proses mempermudah komunikasi. Sehingga semakin banyak kata yang di kuasai oleh anak tersebut, maka semakin banyak pula pengetahuan dan gagasan yang dikemukakan. Kualitas keterampilan berbahasa seseorang tergantung pada kuantitas kosakata yang dimilikinya (Tarigan, 1997).

Lain halnya dengan seorang anak tunarungu yang dalam perkembangan salah satu organnya mengalami hambatan yaitu dalam kemampuan pendengaran.

Menurut Effendi (2009) "Jika dalam proses mendengar terdapat satu atau lebih organ telinga bagian luar, organ telinga bagian tengah, dan organ telinga bagian dalam yang mengalami ganguan atau kerusakan disebabkan penyakit, kecelakaan, atau sebab lain yang tidak diketahui sehingga organ tersebut tidak dapat menjalankan fungsinya dengan baik, keadaan tersebut dikenal dengan berkelainan pengengaran atau tunarungu". Anak yang berada dalam keadaan kelainan pendengaran seperti itu disebut anak berkelainan pendengaran atau anak tunarungu.

Adanya perkembangan teknologi yang semakin pesat, dapat memperoleh pendidik atau guru untuk menyampaikan pembelajaran di sekolah. Salah satunya adalah gadget atau yang dikenal dengan HP (smartphone) yang terdapat banyak aplikasi/ software yang bisa dimanfaatkan oleh guru dalam menyampaikan materi di kelas.

Dari penelitian sebelumnya memperoleh informasi apakah penelitian yang serupa pernah dilakukan atau tidak. Dari hasil kajian penelitian sebelumnya yang berjudul pengembangan aplikasi pengenalan dasar bahasa isyarat sebagai media pembelajaran berbasis android yang dikemukakan oleh Yulia dan Dewi pada tahun 2015. Sementara itu peneliti memfokuskan kajian pada kosakata yang bervariasi, menarik, mudah, bermanfaat dan menyenangkan bagi siswa.

Berdasarkan hasil pengamatan pada saat Kajian Praktik Lapangan (KPL) peneliti melakukan pengamatan dengan siswa tunarungu. Siswa sedikit mendapatkan kesulitan dalam proses memahami kosakata. Kesulitan tersebut terlihat ketika siswa di minta membaca atau menyebutkan huruf. Dalam proses pembelajaran oleh pendidik tentunya telah mengajarkan bahasa indonesia khususnya kosakata dengan menggunakan alat bantu media kartu huruf dan kata. Hal ini terjadi terhadap siswa tunarungu kelas I SLB Eka Mandiri Kota Batu. Pada saat siswa di minta membaca siswa hanya melihat saja, siswa juga menunggu gurunya membaca dan menyebutkan huruf apa yang akan guru tunjukkan sedangkan siswa hanya mampu menebak kata apa yang diberikan oleh guru sesuai dengan kemampuan kosakata yang diketahui. Siswa lebih tertarik saat belajar dengan menggunakan media yang bergambar namun siswa juga lebih mudah 
merasa bosan dengan media yang biasa digunakan mampu memahami kosakata dalam bahasa yang mereka lakukan sehari-hari

Media yang sering kali digunakan oleh para guru dalam membantu penyampaian pembelajaran kosakata ialah menggunakan media kartu kata. Bentuk latihan tulis yang juga ditugaskan oleh guru yaitu menulis kata-kata yang telah guru berikan tujuannya ag memudahkan siswa mengingat kosakata. Berdasarka penelitian yang dilakukan dengan media diatas terdapa kelemahan yaitu siswa mudah bosan dengan apa yang diajarkan oleh guru tersebut sehingga muncul gagasa untuk menggunakan media lain agar siswa lebih tertarik dan tidak mudah bosan dalam menerima pembelajara dikelas dan juga agar siswa mampu melakukan proses pembelajaran mengenai kosakata secara mandiri di tempat masing-masing. Hal itu dilandasi jug karena siswa tunarungu sudah dapat mengoperasikan Smartphone. Ini didukung hasil uji coba yan dilakukan peneliti kepada siswa dalam mengoperasika Smartphone dan hasilnya menunjukkan bahwa siswa mampu mengoperasikan perangkat tersebut dengan panduan dari guru pembimbing.

Berdasarkan pertimbangan dari masalah yang dirasakan oleh siswa dan berdasarkan pada uraia di atas maka peneliti terdorong untuk melakuka sebuah penelitian dengan judul Pengembangan media pembelajaran kosakata anak untuk tunarungu kelas SLB Eka Mandiri Kota Batu. Dari proses dan has penelitian ini diharapkan anak tunarungu dapat tertari dengan mata pelajaran Bahasa Indonesia kosakata. Selain faktor rendahnya kemampuan pendengara yang dimiliki oleh anak tunarungu untuk meningkatka pemahaman dalam berbahasa maka diperlukan media pembelajaran yang konkrit dan cara pembelajara yang berkala, menarik dan menyenangkan.

Dari permasalahan yang dihadapi anak tunarungu tersebut dengan menggunakan aplikasi permainan sebagai salah satu media pembelajaran berbasis android maka diharapkan akan lebih meningkatkan kemampuan dalam pemahaman kosakata anak tunarungu sehingga dengan demikian kemampuan kosakata pun akan semakin berkembang.

Pembelajaran dalam pemahaman pengetahuan kosakata siswa tunarungu dengan aplikasi permainan berbasis android sebagai media pembelajaran ini diharapkan lebih mudah dicapai mengenai target pembelajaran yang diinginkan serta komunikas yang dijalin lebih komunikatif antara siswa dengan sesama maupun dengan guru atau orang lain. Aplikasi ini merupakan aplikasi permainan menggunakan perangkat smartphone dan berisikan tentang huru, gambar tersebut mengandung 1 deskripsi makna kata yang dapat mewakili bermacam-macam benda.

Tujuan penelitian dan pengembangan ini adala menghasilkan media pembelajaran melalui aplikasi permainan berbasis android untuk anak tunarung kelas I yang layak digunakan untuk meningkatkan kemampuan kosakata.

\section{METODE}

Penelitian ini menggunakan metode penelitian dan pengembangan yang dikembangkan oleh Borg dan Gall (Sukmadinata 2013). Dari model reseach an development kemudian peneliti menyesuaikan menjad sebuah model yang ringkas dan sederhana. Dikarenaka metode yang digunakan Borg dan Gall membutuhka waktu yang lama dan biaya yang lebih besar. Adapu langkah-langkah dari penyesuaian model reseach and development yang digunakan dalam penelitian in adalah sebagai berikut: (1) Menentukan potensi dan masalah penelitian (2) Mengumpulkan informasi (3) Mendesain produk (4) Validasi desain (5) Melakukan revisi (6) Uji coba terhadap suatu kelompok kecil (7)

(akukan revisi dan hasil akhir pengembangan.

Berdasarkan prosedur pengembangan pada penelitian ini, jenis data yang diperoleh adalah dat kualitatif dan data kuantitatif. Data kualitatif diperole dari berbagai tinjauan para ahli yang berupa saran masukkan dan evaluasi. Data kuantitatif di perole dari data penelitian awal (analisis kebutuhan) untuk mengetahui persentase kebutuhan produk yang aka dikembangkan serta dari data uji kelompok kecil.

Instrumen yang digunakan dalam penelitian pengembangan Media Pembelajaran Kosakata Untuk Anak Tunarungu Kelas 1 SDLB Eka Mandiri Kota Batu menggunakan angket untuk pengumpulan data. Lembar angket pada penelitian ini di kembangkan berdasarkan kriteria pemilihan materi dan media .

Teknik analisis data yang digunakan dalam penelitian ini adalah teknik anlisis deskriptif. Hasil dari analisis data deskriptif ini akan digunakan dalam penyempurnaan penelitian pengembangan ini. Analisis dari ahli media, ahli materi dan siswa kelas I tunarung

\section{HASIL DAN PEMBAHASAN}

\section{Hasil}

Produk pengembangan media pembelajaran melalui aplikasi permainan berbasis android ini menggunakan dua ahli evaluasi, yaitu ahli media da ahli materi. Teknik pengumpulan data evaluasi dari para ahli menggunakan angket yang berisi tentan pertanyaan dan saran mengenai hasil dari produk penelitian yang akan dibuat dan hasil evaluasi par ahli.
Tabel 1. Data Hasil Validasi Para Ahl

Evaluasi Ahli Berdasarkan hasil evaluasi ahli materi diperoleh presentase $92,85 \%$ dan termasuk dalam kriteria baik

Ahli Media Berdasarkan hasil evaluasi ahli materi diperoleh presentase $95,83 \%$ dan termasuk dalam kriteria baik

Tabel 2. Data Hasil Uji Coba Kelompok Kecil Skor Pre-test an Post-test

\begin{tabular}{crcc}
\hline \multirow{2}{*}{ No. } & \multirow{2}{*}{ Nama } & \multicolumn{2}{c}{ Hasil } \\
\cline { 3 - 4 } & & Pre-test & Post-test \\
\hline 1. & Aggis & 80 & 100 \\
2. & Bayu & 50 & 75 \\
3. & Lucky & 60 & 75 \\
\hline Jumlah & 60 & 190 & 250 \\
\hline Rata-rata & 63,33 & 83,33 \\
\hline
\end{tabular}

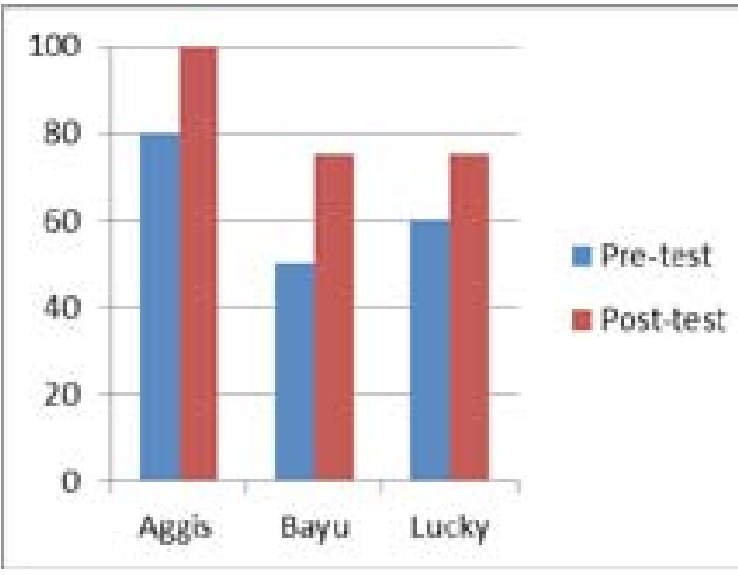

Gambar 1. Data Hasil Uji Coba Kelompok Kecil Skor Pre-test an Post-test

Aplikasi permainan berbasis android sebagai ala revisi berdasarkan penilaian tahap uji validasi ahli, kemudian melakukan ujicoba aplikasi dengan subjek yaitu siswa kelas I SLB Eka Mandiri Kota Batu. Siswa yang dijadikan subjek dalam proses uji coba pada kelompok kecil ini adalah 3 siswa tunarungu.

Tujuan uji coba kelompok kecil ini adalah untuk mendapatkan kelayakan mengenai media pembelajaran. Proses Uji coba dari kelompok kecil ini menggunakan dengan siswa melakukan proses belaja berbasis android ini mulai dari awal membuka aplikasi hingga akhir dan diberikan soal pre-test dan post-test untuk siswa. Hasil uji coba dari kelompok kecil dapa dilihat pada table 3.

Berdasarkan data yang disajikan Gambar menghasilkan kesimpulan bahwa nilai rata-rata skor pre-test seluruh peserta didik adalah 63,33 , sedangkan nilai rata-rata pada post-test seluruh peserta didik adalah 83,33 , kesimpulan yang diperoleh adalah menunjukkan bahwa media pembelajaran aplikasi permainan berbasis android nateri kosakata bagi siswa tunarungu adalah termasuk dalam kriteria baik sekali atau media valid bisa digunakan.

\section{Pembahasan}

Media pembelajaran merupakan sebuah alat yang dapat membantu pendidik dalam menyampaikan suatu yang akan diajarkan kepada siswa dengan menggunakan sebuah perangkat atau benda. Sedangkan menurut Susilana dan Riyana, (2009:7) mengatakan bahwa "Pada awal sejarah pembelajaran, media hanyal merupakan alat bantu yang dipergunakan oleh seorang guru untuk menerangkan pelajaran. Alat bantu yang mula-mula digunakan adalah alat bantu visual, yaitu berupa sarana yang dapat memberikan pengalaman visual kepada siswa, antara lain untuk mendorong motivasi belajar, memperjelas dan mempermudah konsep yang abstrak, dan mempertinggi daya serap atau retensi belajar". Sedangkan menurut Schramm dalam Suliana dan Riyana (2011:6)."media pembelajaran adalah teknologi pembawa pesan yang dapat dimanfaatkan untuk keperluan pembelajaran"

Pada pembahasan tentang media, istilah media pendidikan dan media pembelajaran pada beberapa literatur menunjukkan makna yang sama dan dapat digunakan secara bergantian Yusufhadi Miarso 2004 dalam (Mawar 2012:11), menyatakan bahwa "media pendidikan adalah berbagai jenis komponen dalam lingkungan siswa yang dapat merangsang siswa untuk belajar". Sementara itu Briggs dalam (Mawar 2012:11) mengemukakan bahwa "media pembelajaran adalah sarana untuk memberikan perangsangan bagi si belajar agar proses belajar terjadi".

Pada hakekatnya dalam proses sistem belajar dikelas merupakan sebuah proses berkomunikasi, penyampaian pesan dari pemberi informasi ke penerima. Informasi tersebut berupa isi atau mengenai ajaran yang disampaikan didalam simbol komunikasi yang tersampaikan secara verbal (kata-kata dan tulisan)
maupun non-verbal. Proses tersebut dinamakan encoding. Sedangkan dalam proses penafsiran simbolsimbol komunikasi tersebut dinamakan decoding.

Permainan (game) adalah setiap kontes antara para pemain yang berinteraksi satu sama lain dengan mengikuti aturan-aturan tertentu untuk mencapai tujuan tertentu pula. Sedangkan menurut (Ditto 2016) "permainan (game) adalah kegiatan yang berisi bermain dan mainan, bermain merupakan kegiatan bermainan. Dan permainan yang mengintegrasikan dan mengkombinasikan materi pelajaran kedalam komponen-komponen permaian merupakan game edukatif”. 


\begin{tabular}{|c|c|c|c|}
\hline 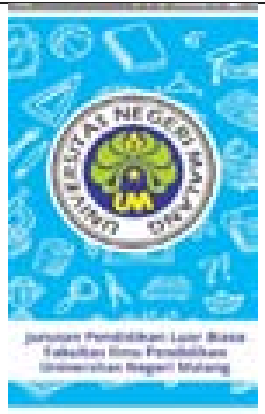 & $\begin{array}{l}\text { Halaman ke } 1 \text { media berisi } \\
\text { tentang logo UM dan } \\
\text { tulisan Universitas Negeri } \\
\text { Malang, Fakultas Ilmu } \\
\text { Pendidikan, Pendidikan } \\
\text { Luar Biasa }\end{array}$ & 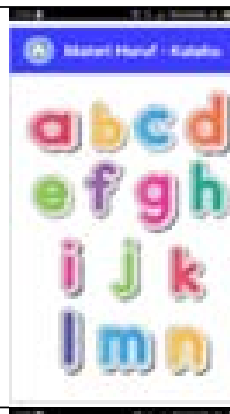 & $\begin{array}{l}\text { Halaman ke } 6 \text { berisi tentang } \\
\text { materi yaitu huruf a sampai } \\
\text { n. }\end{array}$ \\
\hline 10 & $\begin{array}{l}\text { Halaman ke } 2 \text { berisi } \\
\text { tentang judul dari media } \\
\text { "KATAKU" }\end{array}$ & & $\begin{array}{l}\text { Halaman ke } 7 \text { berisikan } \\
\text { tentang menampilkan } \\
\text { huruf yang telah dipilih } \\
\text { dalam tampilan lebih besar, } \\
\text { misalnya huruf a, setelah } \\
\text { huruf a muncul tekan huruf } \\
\text { a untuk melihat contoh } \\
\text { gambar dan kata dari huruf } \\
\text { a }\end{array}$ \\
\hline 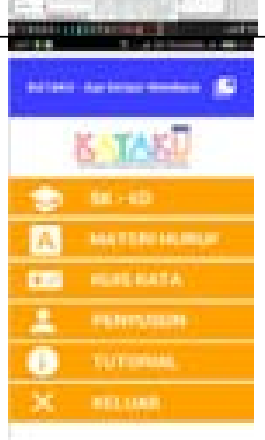 & $\begin{array}{l}\text { Halaman ke } 3 \text { berisi tentang } \\
\text { pilihan tombol menu untuk } \\
\text { masuk menu SK-KD, } \\
\text { Materi, Kuis Kata dan } \\
\text { tentang penyusun, tombol } \\
\text { tutorial permanian dan } \\
\text { tombol keluar }\end{array}$ & $\begin{array}{l}\text { ayam } \\
44 \quad "\end{array}$ & $\begin{array}{l}\text { Halaman ke } 8 \text { berisi tentang } \\
\text { tampilan dari contoh } \\
\text { gambar dan kata dari huruf } \\
\text { yang dipilih, misalnya } \\
\text { a - ayam, kemudian tekan } \\
\text { tombol » (selanjutnya) } \\
\text { untuk melanjutkan ke huruf } \\
\text { selanjutnya dan tombol « } \\
\text { (kembali) untuk kembali } \\
\text { ke menu huruf abjad. Dan }\end{array}$ \\
\hline 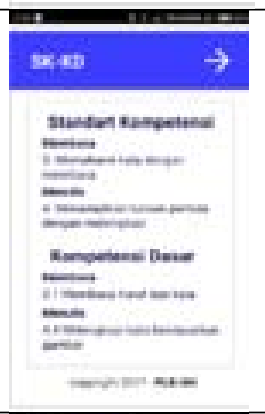 & $\begin{array}{l}\text { Halaman ke } 4 \text { berisi tentang } \\
\text { SK - KD materi yang akan } \\
\text { dibahas dan pilih tombol } \\
\text { kembali ke MENU untuk } \\
\text { melihat materi yang akan } \\
\text { dibahas }\end{array}$ & $\begin{array}{l}\text { Level 1 } \\
\text { Level 2 } \\
\text { Level } 3 \\
\text { Level } 4\end{array}$ & $\begin{array}{l}\text { seterusnya sampal huruf } \\
\text { terakhir n } \\
\text { Halaman ke 9 berisi tentang } \\
\text { tombol level 1-4 dan, setiap } \\
\text { level terdiri dari } 2 \text { kuis kata } \\
\text { atau soal. }\end{array}$ \\
\hline 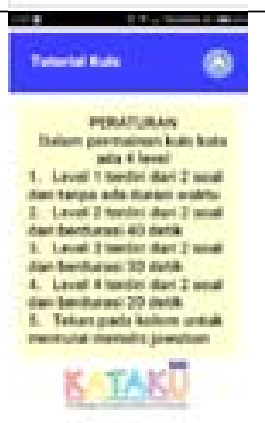 & $\begin{array}{l}\text { Halaman ke } 5 \text { berisi tentang } \\
\text { Tutorial permanian dan } \\
\text { pilih tombol kembali ke } \\
\text { MENU untuk melihat } \\
\text { materi yang akan dibahas }\end{array}$ & Exas & $\begin{array}{l}\text { Halaman } \mathrm{Ke} \quad 10 \text { berisi } \\
\text { tentang soal latihan, } \\
\text { misalnya gambar capung, } \\
\text { anak harus memilih huruf } \\
\text { yang sesuai dengan gambar. } \\
\text { Kemudian tekan tombol biru } \\
\text { untuk mengetahui jawaban } \\
\text { benar atau salah. }\end{array}$ \\
\hline
\end{tabular}

Dengan kata lain permainan atau game edukatif dalah permainan yang mengkombinasikan mater pelajaran yang memiliki konten disetiap pemainnya dan mempunyai aturan-aturan tertentu dan mencapai tujuan tertentu jug

Menurut Mufti Salim (Soemantri 2007) menyimpulkan bahwa "Anak tunarungu adalah anak yang mengalami kekurangan atau kehilangan kemampuan mendengar yang disebabkan oleh kerusakan atau tidak berfungsinya sebagian atau seluruh alat pendengaran, sehingga ia mengalami hambatan dalam perkembangan bahasanya dan memerlukan bimbingan dan pendidikan khusus untuk mencapai kehidupan lahir batin yang layak"

Ada dua hal yang menjadi ciri khas hambatan anak tunarungu dalam aspek kebahasaannya. Pertama konsekusensi akibat kelainan pendengaran (tunarungu) berdampak pada kesulitan dalam menerima segala macam rangsangan bunyi atau peristiwa bunyi yang ada di sekitarnya. Kedua, akibat keterbatasannya dalam menerima rangsangan bunyi pada gilirannya penderita akan mengalami kesulitan dalam memproduksi suara atau bunyi bahasa yang ada di sekitarnya. Kemunculan kedua kondisi tersebut pada anak tunarungu, secara langsung dapat berpengaruh terhadap kelancaran perkembangan bahasa dan bicaranya.

Terhambatnya perkembangan bahasa dan biacara anak tunarungu jelas merupakan masaleh utama karena bicara perkembangan basa dan bicara bagi manusia mempunyai peranan yang vital. Memang sulit dibuktikan tentang kemampuan berfikir seseorang anpa aktulisasi lewat ekspresi lisan (bicara) maupun penulisan bahasa (tulisan).

Bagi anak normal untuk memahami tentang peristiwa benda yang pernah dikenalnya bukanlah suatu yang sulit, karena dapat memahami melalu penglihatan dan pendengaran serta dibantu indra yang lain. Untuk anak yang sudah memahami lambang atau simbol bahasa yang diwujudkan dalam bentuk huruf, ketika benda itu dapat dilihat dan didengar kemudian diasosiasikan melalui sebuat rangkaian huruf sehingga menjadi sebuah kata atau kalimat bermakna.

Media pembelajaran melalui aplikasi permainan berbasis android merupakan media pembelajaran yang berisikan tentang kumpulan huruf (a-n), objek gambar, kosakata dari gambar untuk anak tunarungu kelas $I$. pembelajaran ini disusun secara menarik, baik dari segi isi maupun tampilan.

Produk pengembangan ini berupa aplikasi berbasis android dengan menggunakan software online "Aplikasi Adobe Flash CS6" yang dapat berjalan pada semua smartphone sebagai aplikasi permainan berbasi ndroid.

Produk pengembangan berupa aplikasi permainan berbasis android yang berisikan tentang huruf, objek gambar, kosakata dari gambar, dan diharapkan mampu menarik dan memudahkan anak tunarungu kelas I SLB untuk meningkatkan kemampuan kosakata.

Produk pengembangan berupa permainan berbasis ndroid dikemas dalam bentuk APK, berisikan nama aplikasi, nama pembuat, gambaran aplikasi dan materi.

\section{KESIMPULAN DAN SARAN}

\section{Kesimpula}

Hasil produk pengembangan berupa media pembelajaran aplikasi permainan berbasis android materi kosakata. Produk ini dikemas dalam bentuk APK. Produk yang dikembangkan dalam bentuk sofware ini memiliki kelebihan yaitu sebagai berikut 1) siswa lebih antusias dan tertarik dalam proses pembelajaran, karena produk yang digunakan sangat menarik, sebab pada penyajiannya lengkap dengan warna yang menarik, huruf-huruf abjad yang berwarna, objek gambar yang beragam dan kosakata dari gambar, 2) lebih mudah dipelajari, karena media dilengkapi dengan gambar sehingga belajar kosakata lebih menarik, 3) produk ini sangatlah praktis untuk digunakan karena ukuran file yang kecil dan bisa digunakan dalam kepentingan pendidikan, terutama dalam pembelajaran pendidikan luar biasa.

Dalam pembuatan produk pengembangan ini, sebelumnya dilakukan evaluasi produk terlebih ahli Eva da nitu, media berbasis aplikasi android ini pangat cocok digun dalom pembelajarn individal cocok bisa belajer dar suber lainnya seperti media dawa pembelajaran kosak

\section{Saran}

Saran Pemanfaatan

Pengembangan dari media pembelajaran berbasis mobile android ini diharapkan dapat membantu penyampaian materi untuk guru, Khususnya untuk pemberian dan penyampaian dalam materi kosakata mata pelajaran bahasa Indonesia, agar pembelajaran dapat lebih menarik lagi dan menyenangkan bagi para siswa. Selain itu, dengan pengembangan produk ini diharapkan siswa dapat menjadi lebih tertarik dalam mengikuti kegiatan pembelajaran mata pelajaran bahasa Indonesia, khususnya kosakata dan diharapkan materi yang disampaikan menjadi lebih mudah dipahami. Agar pemanfaatan produk ini bisa maksimal diperlukan peran aktif dari seorang guru dan orang tua siswa. Produk ini bisa dimanfaatkan sebagai media pendukun, dimanapun tempatnya, tidak tergantung pada jarak belajar.

Dalam upaya penyebaran produk ini, peneliti 
memberikan saran sebagai berikut:

Sebelum disebarkan kelingkup yang lebih luas, sebaiknya produk ini disusun dan dievaluasi dengan saran yang ingin dituju apa saja dan kurikulum yang berlakuitu apa saja.

Agar proses dari pengembangan media pembelajaran aplikasi permainan berbasis android ini dapat digunakan lebih luas sehingga perlu dilakukan penelitian dan pengembangan lebih lanjut pada langkah penelitian pengembangan ke 8-10 sesuai dengan langkah dari Borg and Gall.

Sebelum produk disebarkan perlu diadakan sosialisasi untuk sekolah yang akan menggunakan produk ini.

Sebelum produk disebarkan perlu adanya perbaikan produk sehingga bisa di patenkan menjadi hak milik oleh HKI.

\section{Saran Pengembangan Produk Lebih Lanjut}

Dalam upaya pengembangan produk ini kearah lebih lanjut, peneliti memberikan saran-saran sebagai berikut :

Untuk subjek penelitian ini sebaiknya dilakukan pada subjek yang lebih luas lagi, baik itu siswa maupun sekolah yang digunakan sebagai kelompok uji coba ini.

Untuk desain aplikasi ini dibuat lebih user friendly (mudah digunakan) dan lebih menarik lagi. Desain yang dapat dipahami oleh berbagai kalangan dan diperbaiki dengan animasi yang lebih menarik.

Untuk berbagai fitur dan variasi lebih dikembangkan lagi sehingga target pengguna yang bisa menggunakan aplikasi ini bisa bertambah dan bisa untuk dijual atau menghasilkan pendapatan dari aplikasi ini.

\section{DAFTAR RUJUKAN}

Arikunto, S \& Jabar, C.S.A. (2014). Evaluasi Program Pendidikan. Jakarta: BUMI AKSARA

Ditto, R.P. (2016). Pengembangan Game Edukatif Berbasis Android Sebagai Media Pembelajaran Akuntansi Di Kelas XI IPS SMA Negeri 1 Imogiri Pada Materi Jurnal Penyesuaian Perusahan Jasa. Skripsi tidak diterbitkan. Yogyakarta : FE UNY

Effendi, M. (2009). Pengantar Psikopedagogik Anak Berkelaianan. Jakarta: Bumi Aksara

Mawar, R. (2012). Efektivitas Penggunaan Media Pembelajaran E-Learning Berbasis Web Pada Pelajaran Teknologi Informasi dan Komunikasi Terhadap Hasil Belajar Siswa Kelas X SMA Negeri 1 Kalasan. Skripsi tidak diterbitkan. Yogyakarta : FT UNY

Somantri, T. S. (2007). Psikologi Anak Luar Biasa. Bandung: Refika Aditama

Sudijono, A (2008). Pengantar Statistik Pendidikan. Jakarta : PT Raja Grafindo Persada
Sukmadinata, N.S. (2005). Metode Penelitian Pendidikan. Bandung : PT Remaja Rosdakarya

Susilana, R. \& Riyana, C. (2009). Media Pembelajaran. Bandung: CV Wacana Prima.

Tarigan, H.G (2015). Pengajaran Kosakata. Bandung: Angkasa

Yulia, N. \& Dewi, T. (2015). Pengembangan Aplikasi Pengenalan Dasar Bahasa Isyarat Sebagai Media Pembelajaran Berbasis Android. Jurnal Algoritma, (Online), 12 (1): 1, http://sttgarut.ac.id/ jurnal/index.php/algoritma/article/view/159/145, diakses 03 Mei 2017. 